\title{
特集 空き家・空き地問題と今後の活用方策【論説】
}

\section{地方都市における空き家対策}

Countermeasures against Empty House in Local City

Hidetaka YONEYAMA : Fujitsu Research Institute

米山 秀隆*

\section{1 空き家の現状}

総務省「住宅・土地統計調查 (速報集計)」に よれば, 2013年の空き家数は全国で820万戸, 空 き家率は $13.5 \%$ と過去最高を記録した。空き家に は,「売却用」(3.8\%),「賃貸用」(52.4\%)，「二次的 住宅 (別荘等)」(5.0\%),「その他」(38.8\%) の 4 つの類型がある。このうち特に問題となるのは, 空き家になったにも関わらず，買い手や借り手を 募集しているわけではなく，そのまま置かれてい る状態の「その他」の空き家である。例えば, 親 の死亡後, そのままにしておくケースがこれにあ たる。住まなくても維持管理を行っていれば問題 はないが, 放置期間が長引くと倒壊したり, 不審 者侵入や放火, 不法投異の危険性が増すなど周囲 に悪影響を及ぼす問題空き家となる。
空き家全体に占めるその他の空き家の割合は, 2008年の $35.4 \%$ から2013年には38.8\%にまで高 まった。地域別では, 三大都市圈はその割合は $30.9 \%$ であるが, 三大都市圈以外は $46.3 \%$ と非常 に高くなっている。その他の空き家率（その他の 空き家 / 総住宅数) を都道府県別でみると, 過疎 化で悩む九州, 四国, 中国地方などの県が上位と なっている（図表 1 ）。

問題空き家となる予備軍が増加している背景に は, (1)人口減少, (2)核家族化が進み, 親世代の空 き家を子どもが引き継がない, (3)売却・賃貸化が 望ましいが，質や立地面で問題のある物件は市場 性がそしい, (4)売却・賃貸化できない場合, 撤去 されるべきだが，更地にすると固定資産税が上が るため, そのまま放置しておいた方が有利, など がある。

\section{(\%)}

\section{2 \\ 10}

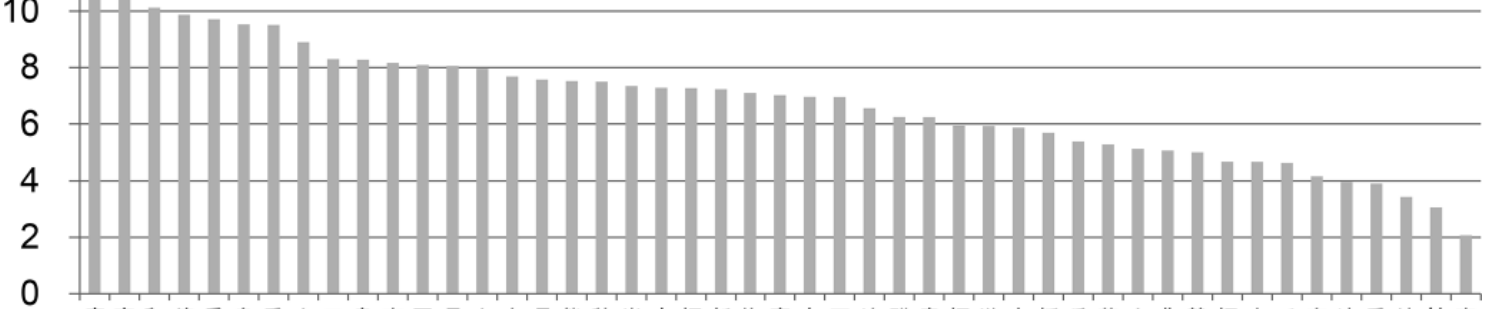

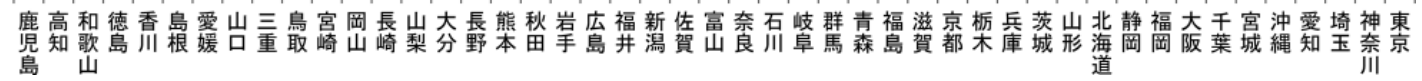

図表 1 その他の空き家率 (2013年)

(出所) 総務省「2013年住宅・土地統計調查（速報集計）」 
空き家対策としては，危険な状態になっている ものについては速やかに撤去していくこと，また， まだ使えるものについては利活用を促していくこ とが必要になる。以下では, 地方都市に扔ける空 き家対策の現状と課題について検討していく。

\section{2 空き家の撤去促進策}

\section{1 空き家管理条例と撤去費補助}

空き家の撤去促進策としては, 空き家管理条例 の制定が進み，2014年 4 月 1 日時点で355の自治 体が施行済みである（国土交通省調べ）。問題空 き家に対し, 指導, 钊告, 命令, 行政代執行を行 うもので，自主撤去を促す効果も生んでいる。施 行状況には地域差が大きく, 半数以上の自治体が 施行している都道府県は, 秋田 $(92 \%)$, 佐賀 $(80 \%)$, 山形 $(71 \%)$, 山口 $(63 \%) 、$ 新潟 $(57 \%)$ の 5 県である（図表 2 ）。施行率が高い自治体は, 人口減少で空き家増加が著しい地域や雪国で空き 家が倒壊の危険に瀕している地域，あるいは空き 家率は低くても住宅が密集しているため問題空き 家が 1 軒でもあると近隣への悪影響が大きい都市 部が含まれている。

ただし，空き家管理条例を制定しても，所有者 に辿り着かないケースや相続放棄されているケー
スもあり，こうした場合の対応は困難になる。相 続放棄されている場合は, 自治体などが家庭裁判 所に相続財産管理人の選任を申し立て，物件を処 分する道があるが，申し立てには予納金が必要で, 物件を売却しても回収できないケースもある。行 政代執行は，豪雪による倒壊の危険に直面してい る自治体で積極的に行っている例があるが，これ も費用の回収は難しい。秋田県大仙市ではこれま で13棟の代執行に踏み切ったが，620万円の撤去 費用が回収できておらず，このほか撤去補助金と して1,400万円以上を支出し, 財政負担が重荷に なっている。

相続財産管理人選任や行政代執行が必要なケー スが限られていれば，自治体はまた，労力的にも 費用的にも対応可能でも, 将来的に人口減少に伴 い，そうした事案が大量に発生した場合，行政の 対応力が限界に達する恐れがある。今後は，そう した場合の迅速な対応手段，また，国による撤去 費用の財政支援が，より必要になってくる可能性 が高い。

すべての危険な空き家を公費で撤去することは 不可能であるため, この問題は最終的には，人口 減少下で今後も居住地として存続させるエリアに ついて，居住環境を維持するために，危険かつ所

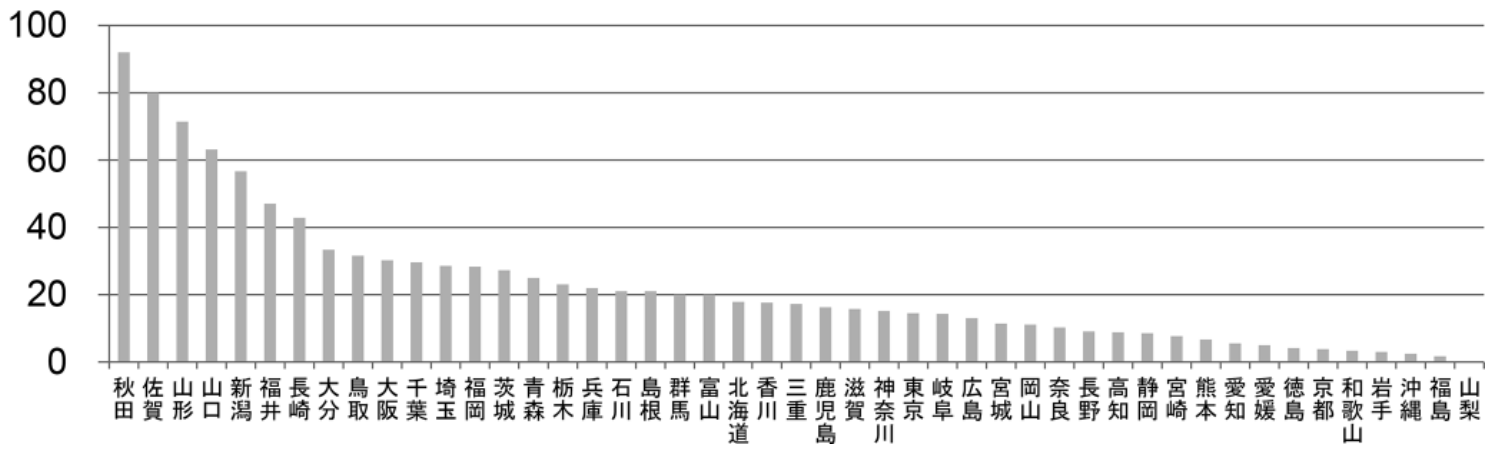

図表 2 空き家管理条例の都道府県別施行率

（出所）国土交通省・すまいづくりまちづくりセンター連合会「空き家住宅情報地方公共団体等による取り組み事例」によ り作成

（注） 1．全自治体に占める，空き家管理条例施行済みの自治体の割合。2014年 4 月 1 日時点で施行済みの条例が対象

2. 和歌山県の施行済み自治体数は 1 つであるが, 県が条例を施行 
有者による自発的な撤去が期待できない空き家に ついて，どれだけ費用を投入して撤去していくか という問題に発展していく可能性が高い。

その意味で参考になるのは, 長崎市の事例であ る。長崎市では2006年度から公費による空き家撤 去を進めてきた。土地建物を市に寄付し，跡地の 利用について地域で話し合い，管理していくこと を前提に，問題空き家を公費で撤去する仕組みで あり，2013度までに41棟撤去した（既成市街地内 が対象)。長崎市の場合, 斜面が多く, 限られた 平地と斜面に住宅が密集しているため, 空き家跡 地の公的利用は, 居住環境改善という点で重要で ある。所有者のためでなく，地域のために公費撤 去するという考え方に基づいている。

また，最近では撤去費を補助する自治体も増え ている。毎日新聞（2014）によれば, 空き家管理 条例施行済みの自治体のうち, 補助を実施してい る自治体は $30.3 \%$ （96自治体）で, 補助実績が最 も多い自治体は広島県点市で 262 件, 総額7,000万 円だった（補助は費用の 3 割で上限30万円）。吳 市は斜面が多く空き家が撤去されにくいため, 広 く補助を行っている。

\section{2 固定資産税の住宅用地特例の扱い}

固定資産税については, 住宅が建っている場合 に，固定資産税の課税標準を 6 分の 1 に軽減する 住宅用地特例は, 住宅不足の時代には, 住宅取得 促進の効果を持った。しかし，住宅が充足した現 在では, 老朽化した住宅でも建っていれば，固定 資産税が低くなるため, 撤去せず残しておくイン センティブを与えている。そもそも特例は, 居住 の用に供する住宅が適用対象のため, 老朽化して 危険な状態になった住宅にまで適用するのはおか しい。こうした考え方の下，危険な状態になった 場合に, 特例解除に踏み切る自治体も出ている。

しかし，特例が解除されただけでは，危険な状 態になった物件が撤去されるかは確実ではない。 更地と同じ税額になるため撤去しても良いと思う か，税金を払えない場合には売却しょうと思うか
もしれないが，撤去には費用がかかり，売ろうに も売れない場合もあるため, 実際には放置される ケースも多いと思われる。こうした事態をできる だけ避けるため, 新潟県見附市では, 更地にして もすぐには税額を上げず， 2 年間の猶予を与えて いる（これまでに 4 軒自主撤去）。これは撤去費 に対する一種の補助金で，こうした工夫も併せて 講じる必要がある。同様の措置は, 富山県立山町 (猶予期間は 2 年間), 福岡県豊前市（猶予期間は 10年間）でも実施する予定（いずれも2015年度開 始）である。

一方, 特例解除は, 特例を受け続けたい空き家 所有者に対しては, 危険な状態と判断されないよ う維持管理を行うよう仕向ける効果を持つ。結果 として危険な空き家は減るが, 残された空き家の 流動化を進めるためには, 別途インセンティブを 考える必要がある。

\section{3 空き家の利活用促進策}

\section{1 空き家バンクの成功要因}

空き家の利活用促進策は，人口減少で悩む地方 の自治体を中心に, 早くから空き家バンクの設置 を中心に進められてきた。空き家バンクとは, 自 治体が空き家の登録を募り，ウェブ上で物件情報 を公開するなどして, 買い手や借り手を探すもの である。しかし, 空き家バンクへの物件登録, 成 約実績には空き家バンクによって差が大きい。現 在でも, 開設以来の累計成約件数が10件未満の空 き家バンクが $49.2 \%$ に達する（移住・交流推進機 構 (2014))。空き家バンクを設置したものの, 開 店休業状態のものが多いことを示している。

そうした中で，実績が出ている空き家バンクは， 所有者による自発的な登録を待つだけではなく, 不動産業者や地域の協力員などと連携して, 積極 的に物件情報を収集しているものである。さらに， 空き家バンクを見て問い合わせがあった場合，物 件案内はもちろんのこと, 生活面や仕事面など 様々な相談にも応じたり, 先に移住した人と引き 合わせたりするなどきめ細かな対応が必要になる。 
こうした対応は，自治体職員だけでは対応しきれ ないため, NPOや地元の協力員, 先に移住した 人などとの連携が必要になる。空き家バンクの成 約件数が最も多い自治体は長野県佐久市であるが (累計成約件数は約270件), 地元に相談員を置く ほか, 東京にも推進員を置いて, 移住者受け入れ に取り組んでいる。

\section{2 空き家の売却・賃貸化のネック}

空き家を売却・賃貸化する場合に，空き家の所 有者にとっては，何が問題となるのだろうか。親 の世代が亡くなって空き家となったケースがその 典型であるが，しばしば指摘されるのは，帰省し た時の滞在・宿泊先や, 従前から置いてあった仏 壇や家財道具の置き場所として引き続き利用して いる所有者が多いという点である。仏壇や家財道 具の処分には，手間がかかる上，心理的にもなか なか踏み切れない場合が多く，そのため空き家と して放置される期間が長くなりがちである。

また，賃貸に踏み切らない理由としては，いっ たん賃貸すると，返還を求めることが困難である と考えている所有者も多い。確かに普通借家契約 の場合はそうした恐れがあるが，期限を区切って 貸す定期借家の制度があまり知られていないこと に問題がある。

過疎地で空き家の増加に悩む島根県江津市にお いて, 空き家所有者に空き家を貸し出すための条 件を聞いたところ，(1)空き家の修繥費用を入居者 が負担，(2)賃貸期間を 5 〜0年に限定する場合， (3)仏壇や位牌の安置場所が確保された場合をあげ る所有者が多かった（総務省・江津市 $(2007)$ )。 (1)は，自治体が改修費などの補助を行うことでク リアでき，(2)は定期借家を活用することでクリア できる。(3は自治体で対応することは困難であり， 所有者自身によって解決してもらうしかないが, 所有者にも金銭的補助を与えることで, 売却・賃 貸化に向けて仏壇などを片付けるインセンティブ をより高めるという方法も考えられる。

以下では, 空き家利活用促進のための各種イン
センティブ施策の事例をみていく。

\section{3 改修費・家賃補助}

空き家バンクに登録された物件を，購入したり 借りたりする場合に，改修費を補助する事例は多 くある。予算により数は限定されるが，改修費の 半分を最大 100 万円などの条件で補助する形がそ の典型的なものである。

家賃補助の事例としては，大分市の事例がある。 大分市では，高度成長期に造成された郊外の一戸 建ての団地（富士見が丘団地）が高齢化して，空 き家が増えていることに対応するため, 同団地に 子育て世帯が住む場合，家賃の 3 分の 2 (最大 4 万円）を補助する仕組みを2011年度に設けた。こ れにより 7 世帯が入居し, 子どもも生まれた。ま た大分市では，これに続く施策として2013年度に, 同市の空き家バンクで中古住宅や空き地を購入し た子育て世帯について, 固定資産税相当額（土地 分）を 3 年間補助する仕組みを設けた。

\section{4 移住促進策と空き家所有へのインセン}

\section{ティブ}

一方，過疎地域では，移住者の呼び込みに熱心 に取り組んでいる。大分県竹田市は，75歳以上の 住民の割合が $25.2 \%$ で全国 1 位（2010年）となる など，高齢化と人口減少が深刻で，2009年に「農 村回帰宣言市」を提唱し, 農村回帰支援センター の設置（移住者へのワンストップサービス）, 改 修費の補助（最大 100 万円），お試し暮らし助成金 (最大6,000円), 集落支援員の配置（旧来の住民 との橋渡し）等の移住促進策に取り組んできた。 この中で特徴的な施策が, 地域の伝統工芸である 竹工芸・紙すき・陶芸などの分野で, 空き家・空 き店舗を活用して起業する場合の補助制度（最大 100万円）である。

移住者を募る場合にネックになるのが職の確保 であるが，竹田市の仕組みは，地域の伝統工芸の 分野で，手に職のある人にターゲットをしぼって 移住してもらうことで，この問題を解決しょうと 
いうものである。すなわち, 職は用意できないの で，最初から手に職を持った人に来てもらおうと いう発想に立っている。2013年度までに 9 件の補 助を実施し，このほか空き家バンクを活用した移 住者は2013年度までに80世帯, 153人に達してい る。

また，竹田市では，移住者に提供する空き家の 物件登録を増やすため, 売却または貸し出した場 合, 成約時に10万円を支給するという，空き家所 有者へのインセンティブも創設した。これにより， 空き家バンクへの登録が増加する効果がみられた という。先に, 空き家所有者が物件を出し渋る要 因として，仏壇などの存在があることを指摘した が，これを自治体自らが処理することは困難であ るものの, その代わり, このようなインセンティ ブを設けることで, 売却, 賃貸化に踏み切る決断 の後押しをすることは可能と考えられる。

\section{4 コンパクトシティ化との連動}

以上，空き家利活用の施策をみてきたが，空き 家利活用をさらに進めていくにあたって考慮しな ければならない問題として, 今後においては市街 地を縮減していく必要があるという問題がある。 地方都市はこの問題が深刻である。地方都市では これまで市街地が外延部に広がってきたが, 今後 は人口減少が急速に進み, 市街地の空洞化が進ん でいく。

コンパクトシティ化の必要性を考えると, 空き 家の中でも利活用できるものは，自ずと選別され ていかざるを得ない。すなわち，集約された市街 地の中に存在する空き家の利活用は積極的に進め ていく必要があり，またそうした地域に問題空き 家が存在する場合には, 居住環境の維持のため除 却を進めていく必要がある。その一方, そうした 市街地からはずれる地域においては, 空き家の利 活用や除却の優先度は低くならざるを得ない。

コンパクトシティ関連の施策としては, 空き家 管理条例の中にまちなか居住推進を盛り込んでい
る松江市の例がある。具体的施策としては, 若年 者がまちなか住宅に住む場合の家賃補助（上限 1 万円， 3 年以内）や，住宅を取得する場合の改修 費等の補助（改修費最大 40 万円，固定資産相当額 最大 5 万円 $\times 5$ 年間, まちなか住宅の場合は補助 率上乗せ), 一戸建ての空き家を賃貸住宅として 貸し出すために行った改修費等の補助（改修費最 大 40 万円，まちなか住宅の場合補助率上乗せ）な どの支援を行っている。

\section{5 今後の課題}

本稿では, 空き家撤去促進策と空き家利活用促 進策の事例についてみてきた。問題空き家の除却 については, 今後も所有者による自主的撤去を促 すのが基本となる。しかし, 将来的には, 所有者 不明の空き家が増えていくことが予想される。こ の問題は最終的には, 人口減少下で今後も居住地 として存続させるエリアについて, 居住環境を維 持するために，危険かつ所有者による自発的な解 体が期待できない空き家について，どれだけ費用 を投入して解体していくかという問題に発展して いく可能性が高い。

利活用促進についても, 今後のコンパクトシ ティ化の必要性を考慮すれば, すべての空き家を 活かすことは不可能で, 利活用できるエリアは自 ずと絞られていく。利活用のための財政支援は, そうしたエリアに重点的に投じていくことで居住 者を呼び込んだり, 空き家を活用した起業を促し たりするなど地域活性化と同時に進めていくこと が効果的と考えられる。

\section{参考文献}

移住・交流推進機構（2014）「『空き家バンク』を活用した 移住・交流促進 自治体調查報告書」3 月

総務省・江津市 (2007)「都市と農山漁村の新たな共生・対 流システムモデル調查報告書」

毎日新聞（2014）「空き家：条例化317自治体，撤去費の補 助導入は 3 割」『毎日新聞』9 月 21 日 